\title{
THE MAGNESIAN SCHISTS FROM THE MORRETES - ANTONINA AREA, PARANÁ
}

\author{
VICENTE A. V. GIRARDI* and PEDRO SANTINI**
}

\begin{abstract}
The magnesian schists from Morretes-Antonina area were derived from ultramafic rocks during two episodes of metamorphism. Amphibolitic schists, mainly tremolitic ones, were the result of the first transformation. During the final transformation much $\mathrm{CaO}$ was lost and considerable water added producing talc, chlorite and serpentine bearing schists.
\end{abstract}

RESUMO Os xistos magnesianos da região Morretes-Antonina derivaram-se de rochas ultramáficas durante duas fases metamórficas que ocorreram na região. Xistos anfibolíticos, principalmente tremolíticos, foram os produtos iniciais. A fase final do processo, caracterizada por uma considerável perda de $\mathrm{CaO}$ e adição de água, resultou em xistos ricos em talco, ocorrendo acessoriamente clorita e serpentina.

INTRODUCTION Cordani and Girardi (1967) present a global geological study of the Morretes-Antonina area, in which gneisses interbedded with small bodies of amphibolite, magnesian schists, magnetite quartzites, chlorite schists and gondites occur. The general strike of the metamorphic rocks is N10-20E. The northwest part of the map exhibits two granite batholiths named, respectively, Graciosa and Marumbi granite (Maack, 1961; Cordani and Girardi, 1967; Girardi, 1969). Tectonic contacts occur between these bodies of alkaline affinities and the regional gneisses. Many diabase dikes cut the metamorphic rocks and the granites, striking generally N50W. They are frequently 20 to $50 \mathrm{~m}$ thick.

Two metamorphic zones have been established for the metamorphic rocks of the area (Fig. 1). The first zone is mainly composed of oligoclase-andesine gneisses, interbedded with oligoclase-andesine amphibolites and andesine-labradorite amphibolites. The second one, which shows apparent retrograde effects (Girardi, 1969; 1971) comprises albite gneisses, albite amphibolites, chlorite schists, magnetite quartzites and magnesian schists. The mineral assemblages of these zones are consistent with the amphibolite and greenschist facies of metamorphism respectively. The samples analysed in this paper, which belong without exceptions to the second zone, are also included in Fig. 1.

A resume of geological events in the area is as follows:

a) 600 m.y.: regional progressive metamorphism;

b) 530 m.y. - granitic intrusions. The batholithic intrusions probably caused synchronous deformation in the metamorphic rocks. This region was infused with solutions. Thus, a diaphoteritic area was produced, which is now characterized by the presence of hydrated low-temperature assemblages of minerals, in the affected gneisses, amphibolites and schists (Girardi, 1969, 1971);

c) 117-147 m.y.: intrusion of diabase dikes (Amaral et al.; 1966, Melfi, 1967).

Mineralogy TALC Talc is a very common mineral. The grains are small (0.02$-0.11 \mathrm{~mm}) . N_{y}$ varies from 1.589 to 1.593 .

\footnotetext{
*Instituto de Geociências - Universidade de São Paulo

**Instituto de Pesquisas Tecnológicas - São Paulo
} 


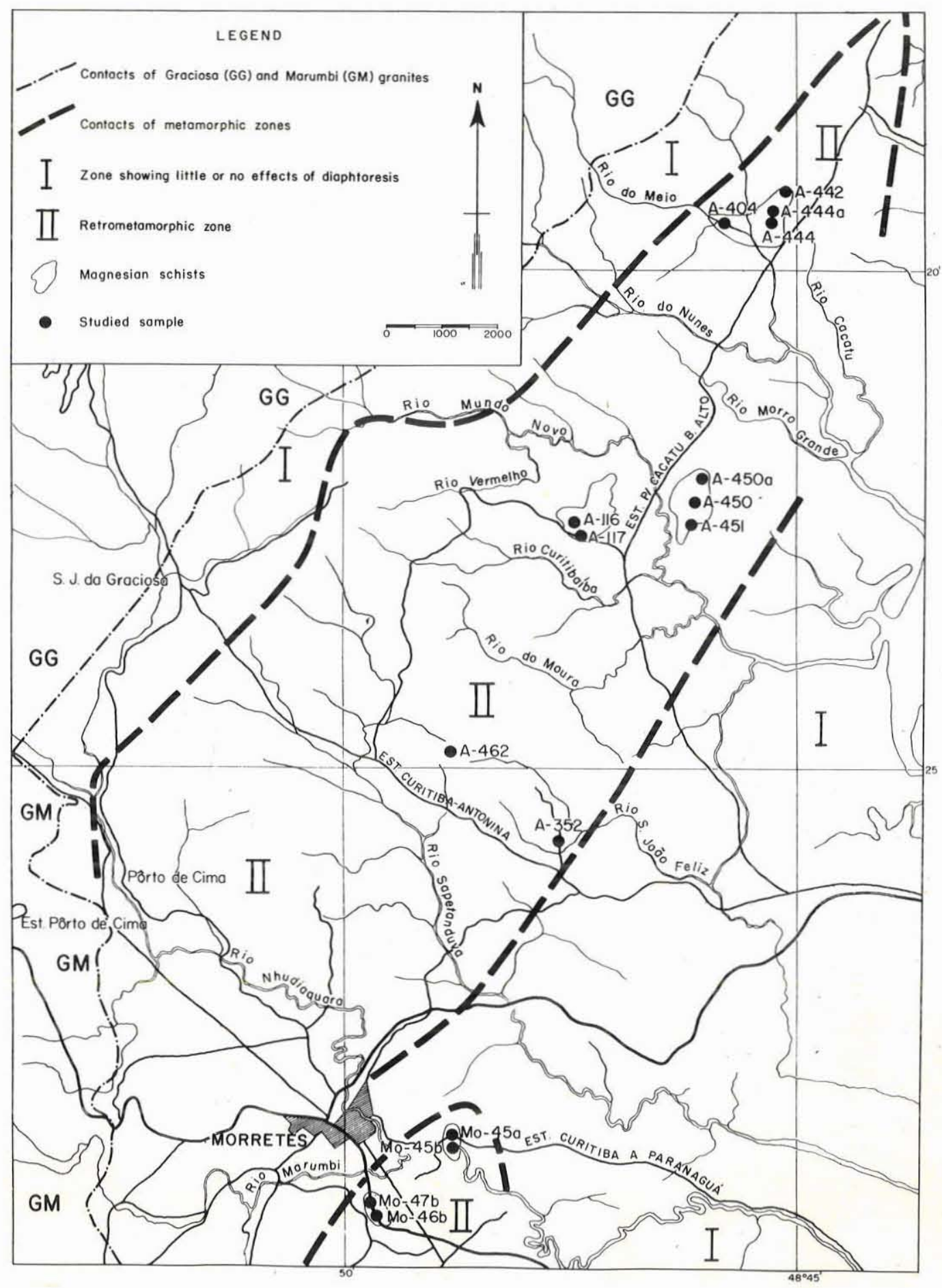

Figure 1 - Distribution of the metamorphic zones in the Morretes-Antonina area, and location of the studied samples. Recent sedimentary layers were not represented on the map 
CHLORITE Chlorites are usually small sized (0.06-0.1 mm), except for porphyroblasts $(0.2-0.8 \mathrm{~mm})$. The pleochroism is weak; $X=$ pale green, $Z=$ yellow. $N_{y}$ varies from 1.588 to 1.603 (Tab. I). The optical sign is positive. The number of heavy atoms, which corresponds very closely to the number of iron atoms has been calculated by using Petruk's (1964) diagram (Fig. 2). By plotting these data and the indices of refraction in Fig. 3, the atomic contents of $\mathrm{Al}$ and $\mathrm{Si}$ have been obtained. To determine the formula composition (Tab. II) the atomic values of $\mathrm{Si}, \mathrm{Al}$ and $\mathrm{Fe}$ have been calculated according to general formula $(\mathrm{Mg}, \mathrm{Fe}, \mathrm{Al})_{6}(\mathrm{Si}, \mathrm{Al})_{4} \mathrm{O}_{10}(\mathrm{OH})_{8}$.

Table I - X-ray and optical data of chlorites

\begin{tabular}{|c|c|c|c|c|c|c|}
\hline Samples & $d(\AA)$ & $h k l$ & $\frac{\mathrm{I}_{002}+\mathrm{I}_{004}}{\mathrm{I}_{003}}$ & Number of heavy atoms & $N_{y}$ & Optical signal \\
\hline \multirow[t]{5}{*}{ Mo-47b } & 14.24 & 001 & & & & \\
\hline & 7.12 & 002 & & & & \\
\hline & 4.74 & 003 & 3.26 & 1.00 & 1.592 & + \\
\hline & 3.56 & 004 & & & & \\
\hline & 2.85 & 005 & & & & \\
\hline \multirow[t]{5}{*}{ A-442 } & 14.28 & 001 & & & & \\
\hline & 7.14 & 002 & & & & \\
\hline & 4.73 & 003 & 3.96 & 1.43 & 1.596 & + \\
\hline & 3.53 & 004 & & & & \\
\hline & 2.96 & 005 & & & & \\
\hline \multirow[t]{5}{*}{$\mathrm{A}-450 a$} & 14.21 & 001 & & & & \\
\hline & 7.10 & 002 & & & & \\
\hline & 4.74 & 003 & 2.38 & 0.30 & 1.595 & + \\
\hline & 3.54 & 004 & & & & \\
\hline & 2.83 & 005 & & & & \\
\hline \multirow[t]{5}{*}{ A-404 } & 14.01 & 001 & & & & \\
\hline & 7.02 & 002 & & & & \\
\hline & 4.70 & 003 & 2.91 & 0.72 & 1.600 & + \\
\hline & 3.53 & 004 & & & & \\
\hline & 2.93 & 005 & & & & \\
\hline \multirow[t]{5}{*}{ A-352 } & 14.26 & 001 & & & & \\
\hline & 7.13 & 002 & & & & \\
\hline & 4.74 & 003 & 3.16 & 0.92 & 1.588 & + \\
\hline & 3.56 & 004 & & & & \\
\hline & 2.81 & 005 & & & & \\
\hline \multirow[t]{5}{*}{ A-444 } & 14.24 & 001 & & & & \\
\hline & 7.13 & 002 & & & & \\
\hline & 4.74 & 003 & 2.66 & 0.53 & 1.592 & + \\
\hline & 3.55 & 004 & & & & \\
\hline & 2.85 & 005 & & & & . \\
\hline \multirow[t]{4}{*}{ A- $-444 a$} & 14.13 & 001 & & & & \\
\hline & 7.06 & 002 & & & & \\
\hline & 4.71 & 003 & 2.82 & 0.65 & 1.603 & + \\
\hline & 3,53 & 004 & & & & \\
\hline
\end{tabular}

ANTIGORITE Serpentine minerals have been found in only two samples, associated with talc in one and chlorite in the other. They are colorless, fine grained $(0.05-0.13 \mathrm{~mm})$ and exhibit blue abnormal interference colors. These minerals were identifield as antigorites, using the X-ray diffraction patterns for serpentines minerals, as published by Whittaker and Zussmann (1956).

D. T. A. analyses were also carried out. Endothermic peaks obtained at $760^{\circ} \mathrm{C}$ and $780^{\circ} \mathrm{C}$, are consistent with the antigorite pattern (Deer, Howie and Zussman, 1963). 


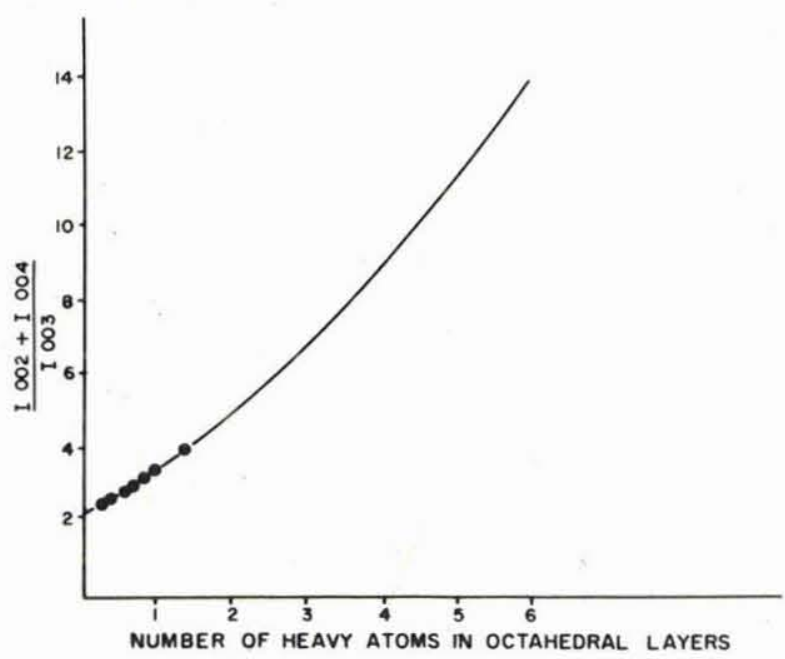

Figure 2 - Chlorites from magnesian schists plotted in Petruk's diagram (1964)

Figure 3 - Chlorites from magnesian schists plotted in Chidester's diagram, modified after Hey (1964)

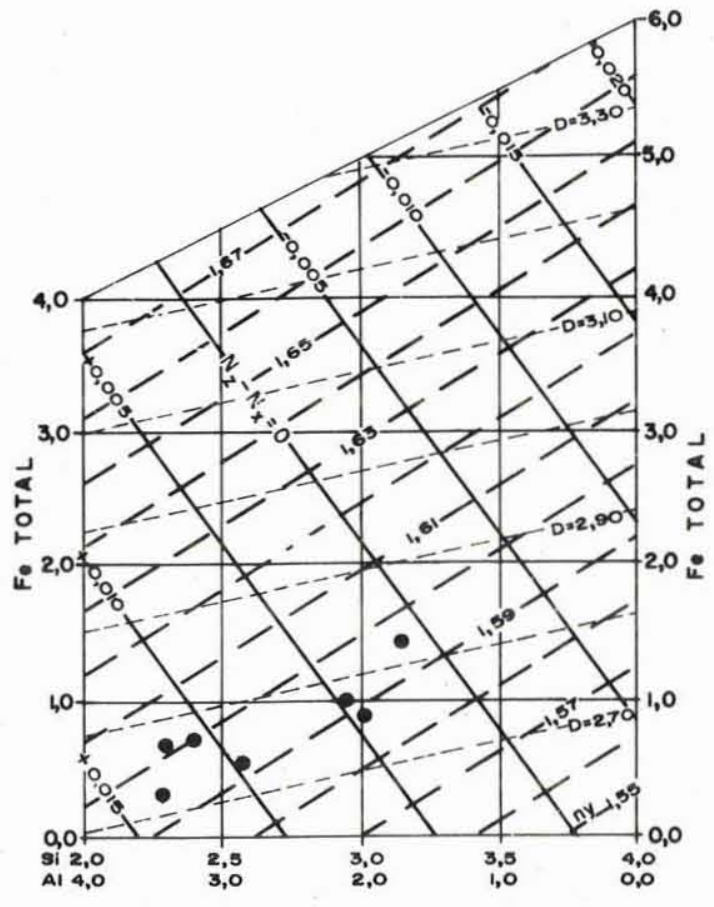

Table II - Calculated chemical formulae of chlorites

A-442 $\left(\mathrm{Mg}_{3.77} \mathrm{Fe}_{1,43} \mathrm{Al}_{0.80}\right)_{6}\left(\mathrm{Al}_{0,90} \mathrm{Si}_{3,10}\right)_{4} \mathrm{O}_{10}(\mathrm{OH})_{8}$

Mo-47b $\left(\mathrm{Mg}_{3.90} \mathrm{Fe}_{1.00} \mathrm{Al}_{1.10}\right)_{6}\left(\mathrm{Al}_{1.10} \mathrm{Si}_{2.90}\right)_{4} \mathrm{O}_{10}(\mathrm{OH})_{8}$

A-352 $\quad\left(\mathrm{Mg}_{4,11} \mathrm{Fe}_{0.92} \mathrm{Al}_{0.97}\right)_{6}\left(\mathrm{Al}_{0.97} \mathrm{Si}_{3.03}\right)_{4} \mathrm{O}_{10}(\mathrm{OH})_{8}$

A-404 $\left(\mathrm{Mg}_{3.68} \mathrm{Fe}_{0.72} \mathrm{Al}_{1,60}\right)_{6}\left(\mathrm{Al}_{1,60} \mathrm{Si}_{2,40}\right)_{4} \mathrm{O}_{10}(\mathrm{OH})$

A-444a $\left(\mathrm{Mg}_{3.63} \mathrm{Fe}_{0.65} \mathrm{Al}_{1.72}\right)_{6}\left(\mathrm{Al}_{1.68} \mathrm{Si}_{2.32}\right)_{4} \mathrm{O}_{10}(\mathrm{OH})_{8}$

A-444 $\left(\mathrm{Mg}_{4,05} \mathrm{Fe}_{0,53} \mathrm{Al}_{1,42}\right)_{6}\left(\mathrm{Al}_{1,42} \mathrm{Si}_{2,58}\right)_{4} \mathrm{O}_{10}(\mathrm{OH})_{8}$

A-450a $\left(\mathrm{Mg}_{3.98} \mathrm{Fe}_{0.30} \mathrm{Al}_{1.72}\right)_{6}\left(\mathrm{Al}_{1.70} \mathrm{Si}_{2.30}\right)_{4} \mathrm{O}_{10}(\mathrm{OH})_{8}$

TREMOLITE Tremolite is the predominant amphibole. The grains $(0.12-1.5 \mathrm{~mm})$ are colorless. The optical data, which are listed in Tab. III, indicate very small or nonexistent amounts of $\mathrm{Fe}^{++}$replacing magnesium (Trögger, 1956).

Table III - Optical data of tremolites

\begin{tabular}{lccc}
\hline Sample & $2 V_{x}$ & $N_{y}$ & $Z \wedge C$ \\
\hline \hline A-450a & $85^{\circ}$ & 1.625 & $17^{\circ}$ \\
A-451 & $79^{\circ}$ & 1.630 & $15^{\circ}$ \\
A-404 & $82^{\circ}$ & 1.630 & $16^{\circ}$ \\
A-450 & $78^{\circ}$ & 1.692 & $17^{\circ}$ \\
A-444a & $80^{\circ}$ & 1.628 & $16^{\circ}$ \\
A-352 & $78^{\circ}$ & 1.622 & $17^{\circ}$ \\
A-442 & $82^{\circ}$ & 1.627 & $17^{\circ}$ \\
\hline
\end{tabular}

HORNBLENDE Hornblende occurs in small amounts, generally as relict grains (0.2$-0.5 \mathrm{~mm}$ ) surrounded by tremolite. The plecroism is weak: $Z=$ pale green, $X=$ yellow. According to the optical data $\left(N_{y}=1.654-2 V_{x}=80^{\circ}\right)$ the grains should contain large amounts of magnesium (Deer, Howie and Zussman, 1963). 


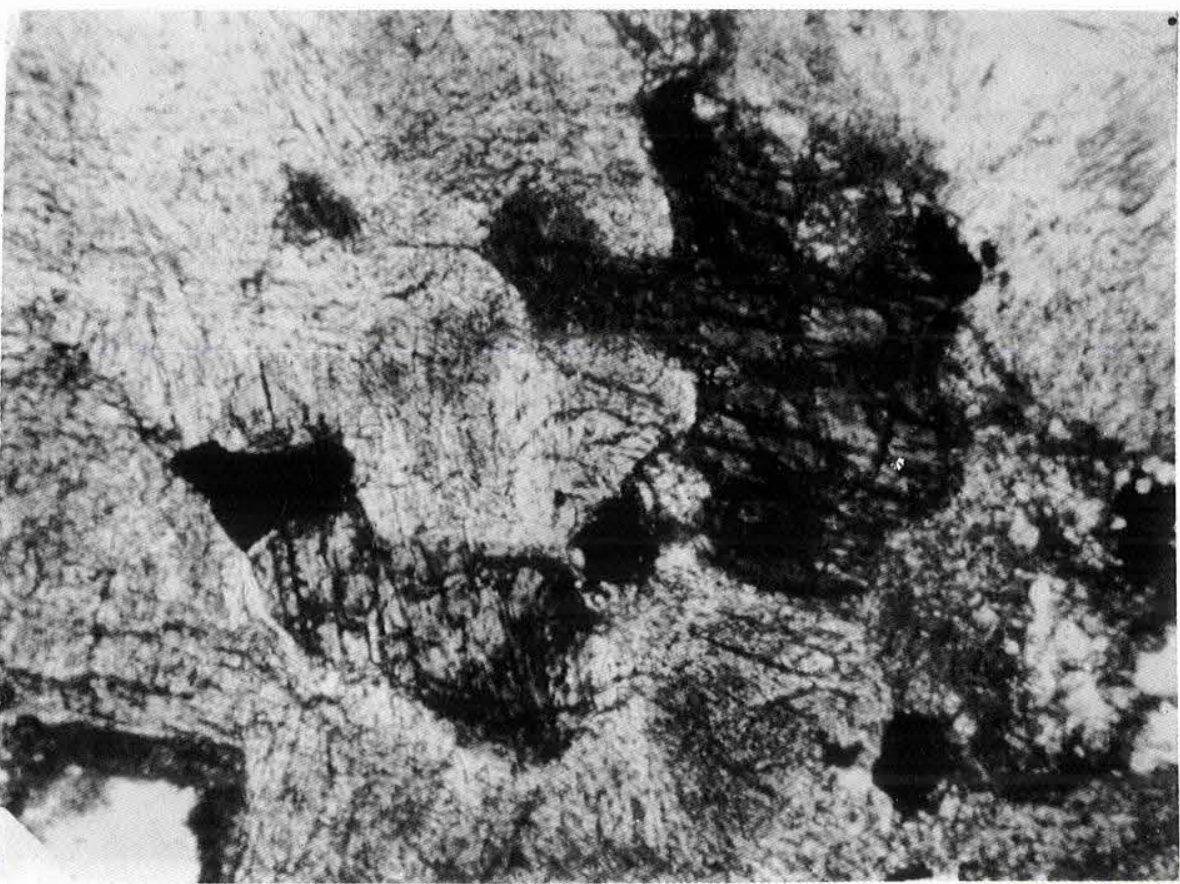

Photomicrograph 1 - Relict grains of hornblende surrounded by tremolite $(\times 400)$

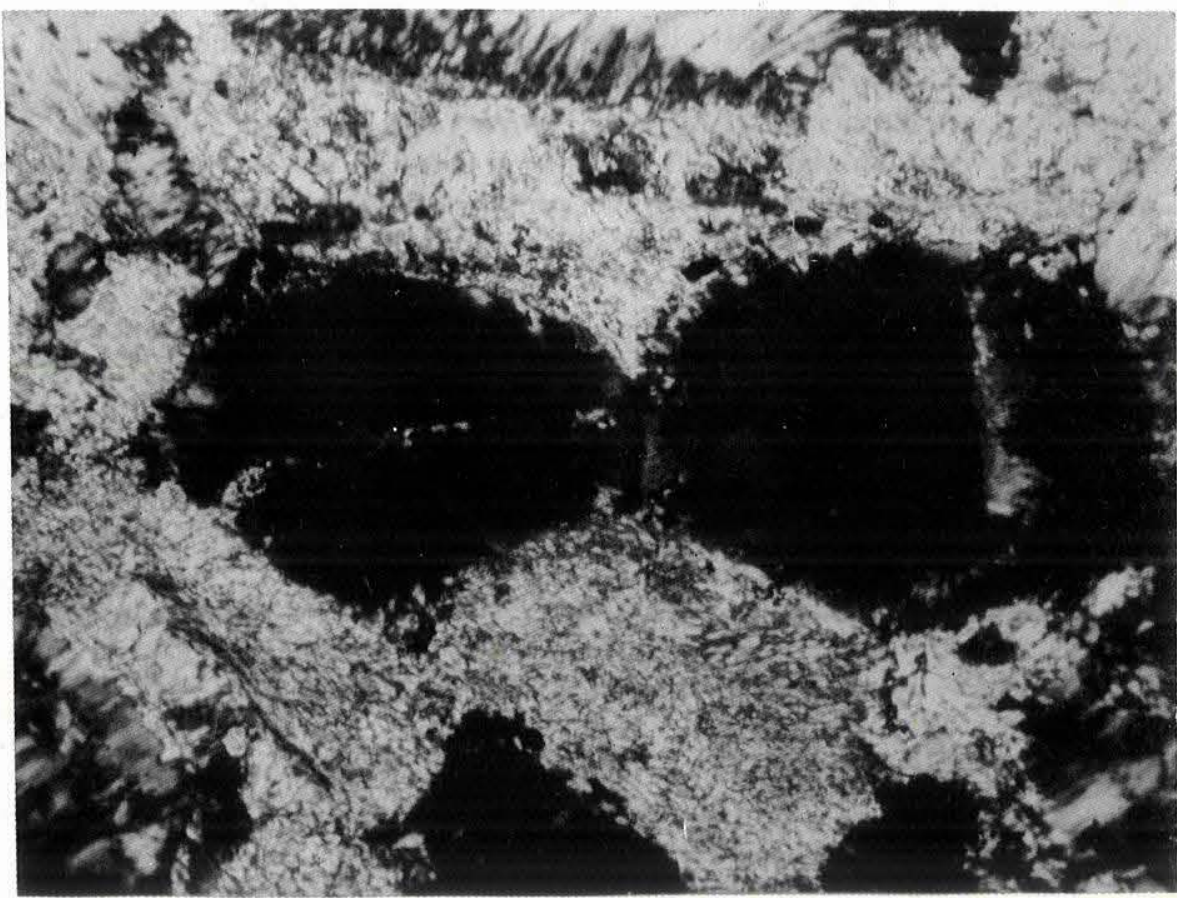

Photomicrograph 2 - Antigorite and magnetite replacing pseudomorphically olivine $(\times 200)$ 


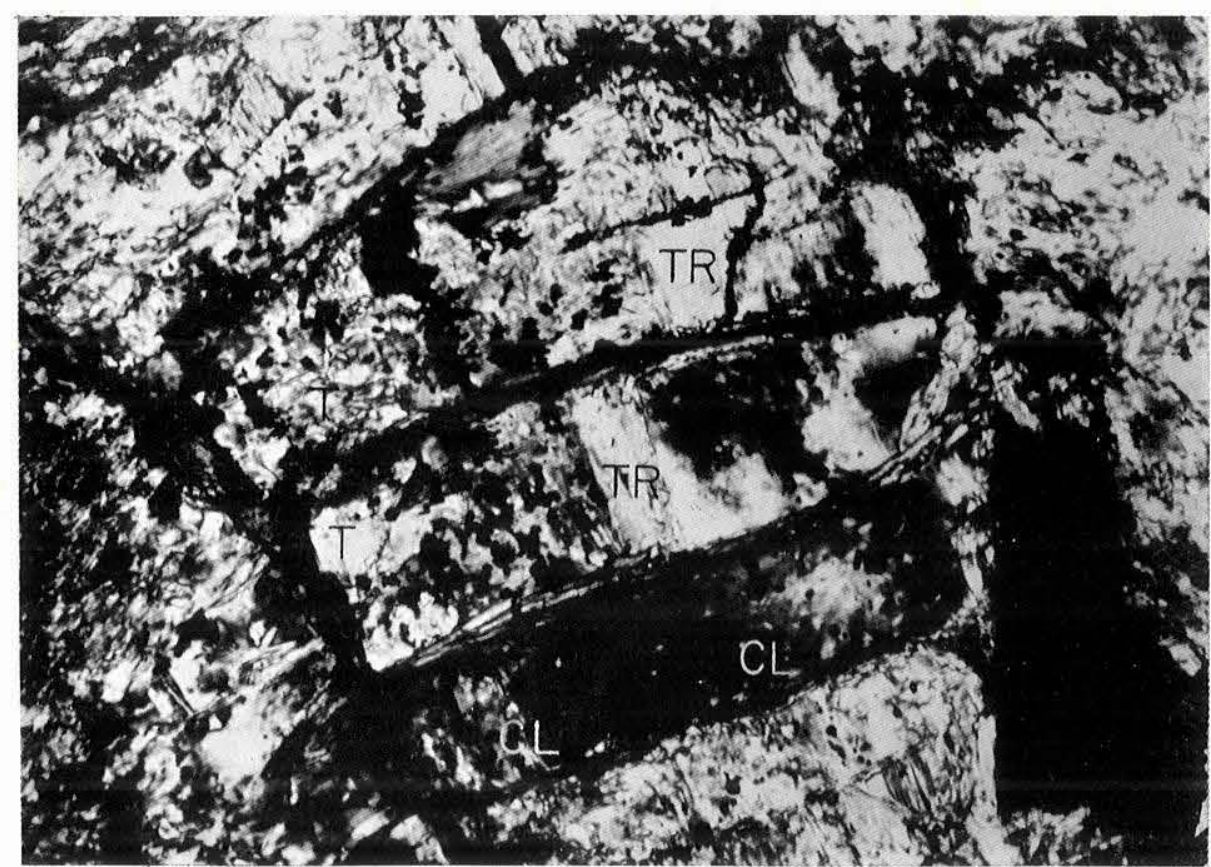

Photomicrograph 3 - Grain of tremolite partially replaced by talc and tremolite. TR, tremolite; CL, chlorite; T, talc. $(\times 300)$

OTHER MINERALS Gummingtonite occurs only in one sample. The grains (0.18$-0.72 \mathrm{~mm})$ are generally associated with tremolite. According to the measured optical data $\left(N_{z}=1.659, Z \Lambda C=20^{\circ}\right.$ and $\left.2 V_{z}=77^{\circ}\right)$ it should be a magnesium rich member of the cummingtonite-grunerite series (Deer, Howie and Zussman, 1963).

Magnetite is very common. Hematite has been found in two samples. Small amounts $(0.2 \%$ and traces $)$ of relict grains of pyroxene, probably diopside or diopsidic augite, occur in two samples. Biotite ( $Z=$ brown, $X=$ yellow), apatite, and rutile are rare acessories.

Petrography and petrology Talc, tremolite and chlorite are the most abundant minerals of the magnesian schists (Tab. IV). These rocks usually show lepidoblastic texture. In some samples, microporphyroblasts of tremolite occur in a fine matrix.

MINERALOGIGAL TRANSFORMATIONS The textural relationships among the main minerals of the magnesian schists indicate their origin and sequence of crystallization (Fig. 5).

Fresh olivine does not occur. It has been replaced pseudomorphicly by antigorite commonly associated with fine-grained by-product magnetite. Hornblendes occur as relict grains partially replaced by tremolite, antigorite or talc.

The extremely rare grains of relict pyroxene demonstrate replacement of pyroxene by tremolite, talc and antigorite. There seem to be two generations of tremolites. Fig. 4 points out the position of the first one. Some thin sections indicate the presence of second generation, probably contemporary with the phyllosilicates.

Talc, chlorite and antigorite are the final products of the mineralogical breakdown. Their crystallization relationships could not be established in detail. 
Table IV - Modal analyses of the magnesian schists

\begin{tabular}{|c|c|c|c|c|c|c|c|c|c|c|c|c|}
\hline & Talc & Tremolite & Hornblende & Cummingtonite & Chlorite & Antigorite & Opaques & Pyroxene & Rutile & Biotite & Apatite & Zircon \\
\hline A-450 & 11.7 & 57.9 & - & 27.4 & 2.6 & - & - & - & 0.3 & 0.1 & - & - \\
\hline A- $444 a$ & 1.4 & 89.0 & 4.7 & - & 1.6 & - & 3.1 & 0.2 & - & - & tr. & - \\
\hline A-404 & - & 86.3 & 5.1 & - & 3.5 & - & 5.1 & - & - & - & - & - \\
\hline A- 442 & 35.4 & 51.0 & - & - & 6.8 & - & 6.8 & - & - & tr. & - & - \\
\hline A-352 & 52.8 & 25.7 & - & - & 15.9 & - & 5.6 & - & - & - & - & - \\
\hline A-444 & 87.5 & - & - & - & 7.4 & - & 5.0 & - & - & - & - & 0.1 \\
\hline A-116 & 92.2 & - & - & - & 4.5 & - & 3.3 & - & tr. & - & - & - \\
\hline Mo- $45 a$ & 91.0 & tr. & - & - & 7.0 & - & 2.0 & - & - & - & - & - \\
\hline Mo-45b & 93.0 & - & - & - & 4.0 & - & 3.0 & - & - & - & tr. & - \\
\hline Mo- $47 b$ & 72.8 & - & - & - & 25.2 & - & 1.8 & - & 0.2 & - & tr. & - \\
\hline $\mathrm{A}-450 a$ & 53.9 & 19.6 & - & - & 21.5 & - & 5.0 & - & - & - & - & - \\
\hline Mo- $46 b$ & 42.0 & - & - & - & - & 50.6 & 7.4 & - & - & - & - & - \\
\hline
\end{tabular}




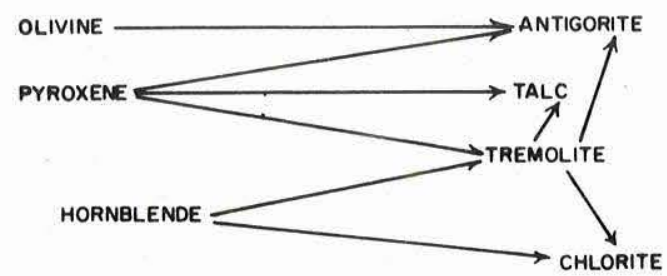

Figure $4-$ Sequence of crystallization of the main minerals of the magnesian schists

THE PARENTAL ROCKS-CHEMICAL TRANSFORMATION DURING STEAT1ZATION AND METAMORPHISM Two genetic paths are recognized for magnesian schists. Sillicification or decarbonatization of sedimentary rocks is one of them. Wright (1950) and Engel (1949) describe two exemples. A Brazilian occurrence of this sort has been studied by Marini and Leprevost (1967). However, steatization of ultramafic rocks is the main process that gives rise to magnesian schists. Talc is the main final product of steatization, whereas minerals as chlorites, serpentines are acessories. In the classical paper written by Hess (1933) the sequence olivine $\rightarrow$ hornblende $\rightarrow$ chlorite talc + carbonate was recognized during the petrogenetic evolution. The relationship between steatization and serpentunization has been discussed by many authors. Hess (1933); Du Rietz (1935); Haapala (1936); Chidester (1962) point out that serpentization procedes steatization. However, Versalo (1965) and Page (1967) describe steatization commencing prior to serpentinization.

The source of fluids responsible for steatization is another debatable topic. In accordance with Hess (1933) and Versalo (1965) steatization in as autometamorphic process. Bowen and Tuttle (1949) ascribe the phenomenon to external sources. In some instances the solutions causing steatization are regarded as deriving from intrusive granites (Cech in Versalo, 1965).

There are no clues of carbonate rocks or minerals in the examined samples. The microscopic studies indicate ultramafic rocks as parental rocks. Nine whole rock chemical analyses were made in order to study the transformations carried out during the steatization (Tab. V). The MSC "modified standard cell", Chidester, 1962) was used to compare

Table V - Chemical analyses of the mugiusian schists

\begin{tabular}{lrrrrrrrrr}
\hline & $\mathrm{A}-444 a$ & $\mathrm{~A}-404$ & $\mathrm{~A}-450$ & $\mathrm{~A}-116$ & $\mathrm{~A}-442$ & $\mathrm{~A}-444$ & Mo-47b & A-450a & Mo-46b \\
\hline \hline $\mathrm{SiO}_{2}$ & 52.00 & 51.80 & 49.10 & 58.20 & 51.00 & 54.30 & 52.10 & 48.00 & 46.40 \\
$\mathrm{Al}_{2} \mathrm{O}_{3}$ & 2.60 & 3.08 & 4.40 & 2,48 & 5.00 & 3.03 & 3.95 & 4.24 & 3.70 \\
$\mathrm{Fe}_{2} \mathrm{O}_{3}$ & 2.15 & 3.87 & 6.72 & 6.00 & 7.02 & 6.83 & 2.02 & 6.70 & 5.38 \\
$\mathrm{FeO}$ & 6.80 & 5.83 & 3.34 & 2.08 & 1.89 & 2.91 & 5.43 & 2.57 & 2.68 \\
$\mathrm{CaO}$ & 12.40 & 11,90 & 9.65 & \multicolumn{1}{c}{ tr. } & 5.25 & 0.20 & tr. & 3.97 & tr. \\
$\mathrm{TiO} \mathrm{O}_{2}$ & 0.44 & 0.35 & 1.55 & 0.16 & 0.15 & 0.37 & 0.24 & 0.40 & 0.30 \\
$\mathrm{MgO}$ & 21.80 & 20.90 & 21.50 & 26.30 & 24.50 & 26.50 & 30.70 & 27.40 & 33.00 \\
$\mathrm{MnO}$ & 0.56 & 0.34 & 0.20 & 0.06 & 0.17 & 0.17 & 0.08 & 0.11 & 0.16 \\
$\mathrm{Na}_{2} \mathrm{O}$ & 0.37 & 0.16 & 0.40 & 0.10 & 0.10 & 0.06 & 0.12 & 0.09 & 0.03 \\
$\mathrm{~K}_{2} \mathrm{O}$ & 0.24 & 0.08 & 0.14 & 0.11 & 0.06 & 0.04 & 0.04 & 0.04 & 0.05 \\
$\mathrm{P}_{2} \mathrm{O}_{5}$ & 0.01 & 0.04 & 0.03 & 0.01 & 0.02 & 0.06 & 0.02 & 0.01 & 0.03 \\
$\mathrm{H}_{2} \mathrm{O}^{+}$ & 0.70 & 2.21 & 2.61 & 4.58 & 4.88 & 5.25 & 5.56 & 6.11 & 7.78 \\
$\mathrm{CO}_{2}$ & 0.22 & 0.29 & 0.14 & 0.11 & 0.07 & 0.11 & 0.11 & 0.15 & 0.22 \\
& & & & & & & & & \\
$\mathrm{Total}$ & 100.29 & 100.85 & 99.78 & 100.19 & 100.11 & 99.88 & 100.37 & 99.79 & 99.73 \\
Density & 3.01 & 2.94 & 2.94 & 2.75 & 2.66 & 2.82 & 2.80 & 2.90 & 2.54 \\
\hline
\end{tabular}


Table VI -- Number of atoms per M.S.C.

\begin{tabular}{|c|c|c|c|c|c|c|c|c|c|c|}
\hline & & A- $444 a$ & A-404 & A- 450 & A-116 & A- 442 & A-444 & Мо- $47 b$ & A- $450 a$ & Mo- $46 b$ \\
\hline & $\mathrm{Si}$ & 53.7 & 51.9 & 49.7 & 54.9 & 46.7 & 52.8 & 49.9 & 48.0 & 40.7 \\
\hline & $\mathrm{Al}$ & 3.2 & 3.6 & 5.2 & 2.7 & 5.4 & 3.4 & 4.4 & 4.9 & 3.7 \\
\hline & $\mathrm{Fe}^{3+}$ & 1.9 & 2.8 & 5.1 & 4.3 & 4.8 & 4.9 & 1.5 & 5.0 & 3.6 \\
\hline & $\mathrm{Fe}^{2+}$ & 5.8 & 4.9 & 2.8 & 1.6 & 1.4 & 2.4 & 4.3 & 2.2 & 2.0 \\
\hline & $\mathrm{Ti}$ & 0.3 & 0.2 & 1.2 & 0.1 & 0.1 & 0.3 & 0.2 & 0.3 & 0.2 \\
\hline & $\mathrm{Ca}$ & 13.7 & 12.7 & 10.4 & - & 5.2 & 0.2 & - & 4.3 & - \\
\hline & $\mathrm{Mg}$ & 33.8 & 31.5 & 32.7 & 37.2 & 33.6 & 38.6 & 44.2 & 39.5 & 43.4 \\
\hline & $\mathrm{Mn}$ & 0.4 & 0.3 & 0.2 & - & 0.1 & 0.1 & - & - & 0.1 \\
\hline & $\mathrm{Na}$ & 0.7 & 0.2 & 0.8 & 0.2 & 0.2 & - & 0.2 & - & - \\
\hline & $\mathrm{K}$ & 0.2 & 0.2 & 0.2 & 0.1 & - & - & - & - & - \\
\hline & $\mathrm{P}$ & - & - & - & - & - & - & - & - & - \\
\hline & $\mathrm{H}$ & 4.8 & 14.8 & 17.6 & 28.2 & 29.7 & 31.0 & 35.6 & 40.7 & 45.4 \\
\hline & C & 0.2 & 0.3 & 0.2 & 0.1 & - & 0.2 & 0.1 & 0.2 & 0.3 \\
\hline Total & $\mathrm{Fe}$ & 7.7 & 7.7 & 7.9 & 5.9 & 6.2 & 7.3 & 5.8 & 7.2 & 5.6 \\
\hline
\end{tabular}

the results graphically (Tab. VI). The M. S. C. is a modified version of Barth's 1948 standard cell of 160 oxygen atoms. Barth points out that for many different kinds of rocks the volumes containing this number of oxigen atoms are very similar, and also contain close to 100 cations. Consequently, analyses recalculated in terms of each kind of cation associated with 160 oxygen atoms can be compared. According to Chidester (1962), in certain metasomatic reactions, particulary those involving alteration of ultramafic rocks, if Barth's standard cell is employed the volumes of different rocks compared will be different. So, Chidester proposes the modified standard cell (M. S. C.). I'his cell is defined by a constant volume: $2064,8 \times N^{-1} \mathrm{~cm}^{3}$, where $N$ is Avogadro's number. By employing Chidester's cell the ions contained by a constant volume of rocks are compared. For the majority of crustal rocks, one M. S. C. contains very nearly 100 cations and 160 oxygen atoms.

The chemical data are compared by plotting the number of atoms of each element in one M.S. C. of each sample against the amount of H. Unfortunately, no ultramafic parental rock could be plotted. Fig. 5 shows the chemical transformations carried out during the transformation of amphibole schists in talc, chlorite and serpentine bearing schists. Loss of calcium and addition of water are the remarkable features of the diagram. The lines for $\mathrm{Si}$ and $\mathrm{Mg}$ seem to show, respectively, small decrease and increase in the amount of these elements. However, the trends are not remarkable. The lines for $\mathrm{Al}$ and $\mathrm{Fe}$ are very nearly horizontal, proving that the amounts of these elements changed very little or did not change during the process.

The first phase of alteration of the ultramafic rocks led to the formation of amphibole bearing schists. Talc, chlorite and rare serpentine were the main final results of the process.

The region comprising the ultramafic rocks has been affected by two metamorphisms. Firstly, by the regional dinamothermal metamorphism and secondly by the retrogressive metamorphism, cleary shown by the diaphtoretic albite amphibolites and gneisses (Girardi, 1969, 1971). Post tectonic granites intruded the metamorphic rocks. The possible contribuition from residual granitic solutions in the retrometamorphic process is a very debatable topic. 


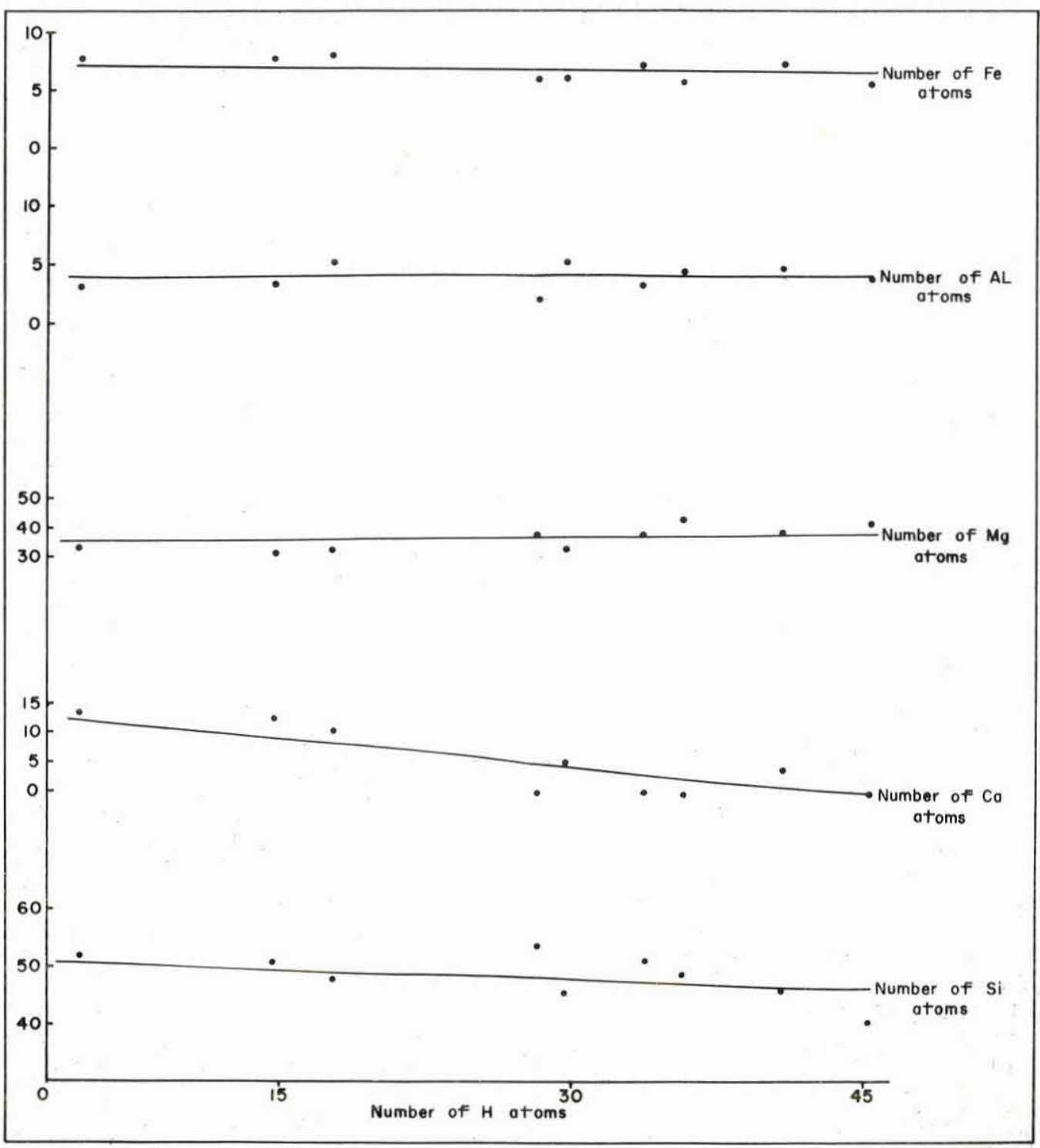

Figure 5 - Variation of chemical composition during stèatization

Acknowledgements This study has been made possible by the financial support of the Conselho Nacional de Pesquisas and Fundação de Amparo à Pesquisa do Estado de São Paulo. Franco Levi and John C. Stormer Jr. kindly read and criticized the manuscript.

\section{REFERENCES}

AMARAL, G., CORDANI, U. G., KAWASHITA, K. and REYNOLDS, J. H. - 1966 Potassium argon dates of basaltic rocks from Southern Brazil Geoch et Cosmoch. Acta, 30 (2): 159-189

BARTH, T.F.W. - 1948 - Oxygen in rocks: a basis for petrographic calculations - J. Geol., 56: $50-60$ 
CHIDESTER, A. H. - 1962 - Petrology and geochemistry of selected talc bearing uliramafic rocks and adjacent country rocks in a North Central Vermont - U. S. Geol. Prof., Paper 345 : 207 pp.

CORDANI, U. G. e GIRARDI, V. A. V. - 1967 - Geologia da Folha de Morretes. Bol. da Univ. Fed. do Paraná - Geologia n. ${ }^{\circ}$ 26, 40 pp.

DEER, W. A., HOWIE, R. A. and ZUSSMAN, J. - 1963 - Rock forming minerals vol. 3, chain silicates. W. Gloves and Sons, Ltd. $271 \mathrm{pp}$.

DU RIETZ, T. - 1935 - Peridotites, serpentinites and soapstones of Northern Sweden, with special reference to some occurrences in Northern Jämtland - Geol. Foren. i Stockholm Förh, 57: $133-260$

ENGEL, A. E. J. - 1949 - New York talcs, their geological features, mining, milling and uses. Mining transactions, 184

GIRARDI, V. A. V. - 1969 - Petrologia das rochas metamórficas da região Morretes-Antonina, Pr. Unpublished Ph. D. thesis, University of São Paulo, Brazil

GIRARDI, V.A. V. - 1971 - Os anfibolitos da região Morretes-Antonina, Pr. Rev. Bras. Geoc:, 1: $43-65$

HAAPALA, P. 1936 - On serpentine rocks of northern Karelia - Bull. Comm. Geol. Finlande, 114: $80 \mathrm{pp}$.

HESS, H. H. - 1933 - Hydrothermal metamorphism of an ultrabasic intrusive of Schuyler, Virginia - Amer. J. Sc., 26: 377-408

HEY, M. H. - 1954 - A new review of chlorites. Min. Mag., 30: 277-292

MAACK, R. - 1961 - Sobre a ocorrência de granitos alcalinos no Estado do Paraná e sua posição dentro das fases orogenéticas algonquianas. Bol. Univ. Paraná: Geologia, 4: 52 pp.

MARINI, O. J. e LEPREVOST, H. - 1967 - Principais recursos minerais do Grupo Açungui, no Estado do Paraná. Geologia do pré-devoniano e intrusivas subseqüentes da porção oriental do Estado do Paraná. Bol. Paranaense Geoc. 23-25: 157-180

MELFI, A. J. - 1967 - Potassium-argon ages for core samples from Southern Brazil. Geoch. and Cosmoch. Acta, 31: 1079-1 089

NALDRETT, A. J. - 1966 - Talc carbonate alteration of some serpentinized ultramafic rocks South of Timmins, Ontario - J. Petrol., 7 (3): 489-499

PAGE, N. P. - 1967 - Serpentinization at Burro Mountain, California, Contr. Mineral. and Petrol., 14: 321-342

PETRUK, W. - 1964 - Determination of heavy atom content in chlorite by means of X-ray diffractometer. Amer. Mineral., 49 (1): 67-71

TRÖGER, W.E. - 1956 - Optische Bestimmung der gesteinsbildenden Minerale. Theil II, Stuttgart, E. Schweitzerbart, Verlagsbuchhandlung, 147 pp.

TURNER, F. J. and VERHOOGEN, J. - 1960 - Igneous and metamorphic petrology, $2 .^{a}$ ed. New York, McGraw-Hill Book Co.

VERSALO, A. 1965 - Talc schists and soapstone occurrences of Finlande. Bull. Comm. Geol. Finland, 215: 9-73

WHITTAKER, E. J. W. and ZUSSMAN, J. - 1956 - The caracterization of serpentine minerals by X-ray diffraction. Min. Mag., 31: 107-126

WRIGHT, L. A. - 1950 - California talcs. Mining transactions: 187 